\title{
VAKSIN MVA85A UNTUK PENCEGAHAN TUBERKULOSIS PADA WISATAWAN
}

\author{
Quedarusman, $H$ \\ Fakultas Kedokteran Universitas Sam Ratulangi Manado \\ (niceguy_anto@yahoo.co.id)
}

\begin{abstract}
ABSTRAK
Tuberkulosis adalah penyakit menular yang dapat menyebar melalui udara, penyakit ini menyebabkan kerusakan serius yang dapat menpengaruhi paru-paru, otak, dan organ lainnya. Tuberkulosis telah menyebabkan bencana signifikan yang berhubungan dengan morbiditas dan mortalitas di dunia dan merupakan salah satu penyebab kematian utama di Indonesia. Teknologi terkini yang maju dalam bepergian dari negara ke negara menyebabkan penyakit ini mampu menyebar dari populasi endemik ke luar negeri. Vaksinasi adalah salah satu cara yang mungkin untuk mencegah terjadinya hal ini, vaksin terbaru MVA-85A dari Universitas Oxford adalah alternatif terbaru untuk melawan tuberkulosis. Wisatawan jangka panjang memiliki kesempatan lebih besar untuk terjadinya kontak dengan penyakit ini, terutama pada balita di bawah 4 tahun. Tidak ada kesepakatan tentang metode untuk mencegah menyebarnya penyakit ini, tetapi ada banyak strategi yang bisa mencegah menyebarnya penyakit ini termasuk menghindari kontak, vaksinasi BCG, dan alternatif lainnya. Dalam penelitian di Universitas Oxford, vaksin baru utnuk melawan tuberkulosis ditemkan dan saat ini sedang menjalani percobaan klinis untuk membuktikan keamanan dan imunogenitasnya di beberapa kelompok orang. Vaksin ini disebut MVA-85A dan dari beberapa percobaan klinis terbukti aman dan imunogenik. Vaksin ini bisa menjadi salah satu cara yang memungkinkan untuk mencegah wisatawan terinfeksi tuberkulosis.
\end{abstract}

Kata Kunci: bepergian; vaksinasi; MVA-85A; penyakit menular; tuberkulosis

\section{DESKRIPSI}

- Tuberkulosis merupakan penyakit menular yang disebabkan oleh bakteri Mycobacterium, terutama Mycobacterium tuberkulosis.

- Tuberkulosis tersering melibatkan gejala pada saluran pernapasan namun mampu menyebar ke organ tubuh lainnya.

- Tuberkulosis sangat menular dan mampu menimbulkan bahaya pada wisatawan yang pergi ke daerah yang endemis tuberculosis yang mengadakan kontak dengan penderita.

\section{GEJALA KARDINAL}

- Batuk merupakan gejala kardinal tuberkulosis biasanya disertai dengan darah (hemoptisis).

- Batuk disebabkan karena infeksi pada saluran napas yang kemudian dapat mengakibatkan erosi saluran napas sehingga darah dalam jumlah kecil dapat bercampur dengan sputum yang dikeluarkan melalui batuk

\section{ETIOLOGI}

- Tuberkulosis disebabkan oleh basil TB yaitu Mycobacterium tuberkulosis.

\section{KLASIFIKASI}

- Tuberkulosis primer yaitu tuberkulosis pada orang yang belum tersensitisasi.

- Tuberkulosis sekunder yaitu tuberkulosis pada pejamu yang telah tersensitisasi.

\section{VAKSINASI TB}

Vaksin TB yang digunakan saat ini adalah vaksin BCG (Bacillus Calmette- Guérin)

BCG diketahui sangat ampuh dalam mencegah tuberkulosis meningitis pada bayi, namun dalam penggunaannya untuk mencegah tuberkulosis paru memberikan hasil yang bervariasi di daerah endemik. Hal ini diperkirakan disebabkan oleh faktor - faktor berikut:

1. Sejarah frekuensi kontak dengan tuberkulosis 
2. Variasi genetik pada strain BCG

3. Variasi genetik dalam populasi

4. Adanya campur tangan dari bakteri Mycobacterium non-tuberkulosis

5. Adanya campur tangan dari infeksi parasit lainnnya

6. Terpapar oleh sinar ultraviolet

Dengan adanya variasi efek tersebut BCG kurang begitu mampu memberikan efek yang dapat membantu mencegah tuberkulosis terjadi di daerah endemik sehingga terbentuknya ide untuk mengembangkan vaksin terbaru dalam memerangi tuberkulosis.

\section{RISIKO BAGI WISATAWAN}

Risiko pada wisatawan tergantung pada

- Tujuan perjalanan

- Durasi perjalanan

- Tipe perjalanan dan kontak dengan siapa

- Usia wisatawan

- Kesehatan wisatawan secara umum

\section{VAKSINASI BARU TB}

Diketahui bahwa vaksin TB saat ini memberikan hasil yang bervariasi dalam pencegahannya terhadap tuberkulosis paru saat ini dikembangkan vaksin terbaru yaitu vaksin MVA-85A. Bakteri Mycobacterium mempunyai antigen pada permukaan selnya yaitu antigen 85A, 85B, dan antigen 85C, antigen ini berperan dalam menjaga integritas dinding sentral yang hidrofobik. Antigen ini menjaga integritas dinding sel dengan mengkatalis transfer asam mikolat ke dinding sel arabinogalaktan dan melalui sintesis trehalosa dimikolat. Selain itu, protein yang disekresikan ini juga menyebabkan terjadinya invasi cepat makrofag alveolar melalui interaksi langsung antara sistem imun host dengan basil yang menginvasi ${ }^{9}$.

MVA-85A dikembangkan oleh Oxford-Emergent Tuberkulosis Consortium Ltd dan the EU-funded research program TB-VAC. Vaksin ini merupakan vaksin hidup yang dilemahkan yang mengekspresikan antigen 85A tuberkulosis yang imunodominan dan dikembangkan untuk dalam strategi booster heterologenik untuk mencegah tuberkulosis. MVA-85A sangat imunogenik pada manusia maupun hewan dengan memberikan respon sel $\mathrm{T}$ CD4+ polifungsional yang kuat ketika diberikan sebagai booster yang mengikuti pemberian vaksinasi BCG atau ketika diberikan pada individu yang sebelumnya terpapar oleh tuberkulosis.

\section{GEJALA-GEJALA TUBERKULOSIS}

- Tuberkulosis dapat berupa tuberkulosis pulmonal dengan gejala-gejala batuk,

- Batuk darah, keringat malam, sakit dada, kehilangan berat badan dan demam.

- Dapat juga bermanifestasi di organ lainnya yang disebut tuberkulosis miliar yang menimbulkan gejala-gejala seperti batuk, limfadenopati, demam, hepatomegali, splenomegali, dan gangguan organ multifungsi.

\section{DAERAH ENDEMIS TUBERKULOSIS}

Di bawah ini dicantumkan negara-negara yang merupakan daerah endemis tuberkulosis beserta dengan insidensinya setiap tahunnya di negara tersebut.

1. Insiden tahunan $40-100 / 100000$

- Afrika: Algeria, Benin, Comoros, Eritrea, Sao Tome and Principe

- Amerika: Belize, Brazil, Republik Dominican, Ecuador, Guatemala, Honduras, Nicaragua, Panama, Paraguay

- Mediteranean timur: Bahrain, Iraq, Libyan Arab Jamahiriya, Morocco, Qatar, Yemen

- Eropa: Armenia, Belarus, Bosnia and Herzegovina, Bulgaria, Latvia, Lithuania, Turkmenistan, Ukraine

- $\quad$ Asia Tenggara: Maldives, Sri Lanka

- Pasifik Timur: Brunei Darussalam, China, Guam, Malaysia, Federated States of Micronesia, Palau, Republik Korea, Vanuatu

2. Insiden tahunan $>100 / 100.000$

- Afrika: Angola, Botswana, Burkina Faso, Burundi, Cameroon, Cape Verde, Central African Republic, Chad, Côte d'Ivoire, Kongo, Equatorial Guinea, Ethiopia, Gabon, Gambia, Ghana, Guinea, GuineaBissau, Kenya, Lesotho, Liberia, Madagaskar, Malawi, Mali, Mauritania, Mozambique, Namibia, Niger, Nigeria, Rwanda, Senegal, Sierra Leone, South Africa, Swaziland, Togo, Uganda, United Republic of Tanzania, Zambia, Zimbabwe

- $\quad$ Amerika: Bolivia, Guyana, Haiti, Peru, Suriname

- Mediteranean Timur: Afghanistan, Djibouti, Pakistan, Somalia, Sudan 
- Eropa: Azerbaijan, Georgia, Kazakhstan, Kyrgyzstan, Moldova, Romania, Russian Federation, Tajikistan, Uzbekistan

- Asia Tenggara: Bangladesh, Bhutan, Korea, India, Indonesia, India, Indonesia, Myanmar, Nepal, Thailand, Timor-Leste

- Pasifik Timur: Cambodia, Kiribati, Lao People's Democratic Republic, Marshall Islands, Mongolia, Papua New Guinea, Philippines, Solomon Islands, Tuvalu, Vietnam

\section{KEAMANAN DAN IMUNOGENITAS VAKSIN MVA85A}

1. Pada orang dengan infeksi laten tuberkulosis Percobaan klinis dilakuakan di Inggris dan dilaksanakan berdasarkan protokol yang disetujui oleh Oxford Research Ethics Commitee.

Efek vaksinasi

- Reaksi lokal yang berhubungan dengan vaksin MVA terjadi dalam minggu pertama setelah vaksinasi dan sebelumnya sudah pernah dilaporkan. Efek lokal tersebut tidak membahayakan. Dosis MVA-85A yang digunakan dalam percobaan ini sama dengan dosis yang digunakan dalam percobaan sebelumnya $^{10}$.

- $\quad$ Gejala sistemik adalah demam $37,5^{\circ} \mathrm{C}$

Imunogenitas vaksin

- Marker inflamasi dimonitor selama studi. Tidak ada peningkatan signifikan dalam pengukuran ESR dan CRP untuk 11 dari 12 peserta selama studi. Salah satu dari subjek mengalami patah tulang pergelangan kaki 2 minggu setelah vaksinasi dan mengakibatkan peningkatan CRP setelah fraktur dari 8 sampai $160 \mathrm{mg} / \mathrm{L}$ dan ESR dari 5 sampai $29 \mathrm{~mm} / \mathrm{jam}$, yang bertahan sampai minggu ke-4. Respon ini dianggap tidak berhubungan dengan vaksinasi. Tidak ada keganjalan yang timbul secara signifikan dalam tes darah hematologi dan biokimia pada subjek dalam studi ini ${ }^{10}$.

- Tidak ada perubahan pada HRCT scan dengan 10 minggu setelah vaksinasi, kecuali pada 1 peserta. Nodul pulmonal $5 \mathrm{~mm}$ divisualisasi pada lobus kanan atas pada pemeriksaan pada minggu ke-10, yang sebelumnya tidak divisualisasikan pada scan sebelum vaksinasi. Namun, limfadenopati hilar yang mengapur dalam volume kecil dideteksi pada subjek yang sama yang menetap sampai minggu ke-10.
Pada scan selanjutnya pada minggu ke-14, telah terjadi resolusi sempurna nodul tersebut. Pasien dalam keadaan asimptomatik dalam periode ini ${ }^{10}$.

- Pada minggu pertama setelah vaksinasi, frekuensi sel T yang menyekresikan IFN- $\gamma$ yang berespon terhadap Ag85A meningkat dengan median $933 \mathrm{SFC} / \mathrm{juta}$ dibandingkan dengan screening. Dalam follow up selanjutnya terjadi peningkatan frekuensi sel $\mathrm{T}$ spesifik terhadap Ag85A secara konsisten. Pada minggu ke 52 respon tersebut tetap lebih tinggi dari awalnya. Respon sel $\mathrm{T}$ pada pool peptida Ag85A juga mengikuti pola yang sama dengan peningkatan median lebih dari 3,637 SFC/juta. Pergerakan respon sel $T$ spesifik Ag85A ini sangat mirip dengan studi sebelumnya MVA-85A dan konsisten dengan pemahaman ekspansi sel $T$ dan kontraksi pada fase memori ${ }^{10}$.

- Analisis arus sitometri menunjukkan bahwa populasi sel $\mathrm{T}$ CD4+ spesifik antigen 85A yang mampu memproduksi sitokin IFN- $\gamma$, IL-2, dan TNF- $\alpha$ setelah vaksinasi. Hasilnya menunjukkan perbedaan dengan respon yang diobservasi di peserta yang terinfeksi Mycobacterium bukan tuberkulosis, subjek yang telah divaksinasi BCG, yang pada awalnya memiliki jumlah sel CD4+ spesifik Ag85A lebih sedikit dan yang terdeteksi hanya memproduksi satu sitokin saja. Vaksinasi MVA-85A Meningkatkan populasi sel T CD4+. Pada minggu pertama lebih dari 50\% sel T CD4+ yang berespon memproduksi IFN- $\gamma+$ IL-2+TNF$\alpha+(3+)$. Pada minggu ke-24 setelah MVA-85A, proporsi lebih besar pada respon spesifik Ag85A yang terdiri dari IFN- $p+$ TNF- $\alpha+(2+)-$ sel T CD4+ yang berespon daripada sebelum vaksinasi. Tidak ada respon sel T CD8+ spesifik yang dideteksi setelah vaksinasi dengan MVA$85 \mathrm{~A}$, yang dipastikan dengan flow cytometry ${ }^{10}$

- Vaksinasi MVA-85A efektif dalam meningkatan sel $T$ spesifik antigen $85 \mathrm{~A}$ yang menyekresikan IFN- $\gamma$ pada subjek dengan infeksi tuberkulosis laten.

- Vaksinasi MVA85A meningkatkan sel T spesifik antigen $85 \mathrm{~A}$ yang menyekresikan IL-3.

- Tidak ada perubahan setelah vaksinasi pada frekuensi median sel $\mathrm{T}$ yang berespon pada antigen Mycobacterium yang disekresikan sebelumnya, ESAT- 6 pada minggu pertama atau minggu ke-52 dan CFP-10 pada minggu pertama atau minggu ke-52. Hasil ini kontras dengan peningkatan frekuensi sel $T$ yang terlihat sebagai respon terhadap Ag85A, gen ini dikode dalam vaksin MVA-85A ${ }^{10}$. 
Kesimpulan

- MVA-85A aman penggunaannya pada pasien yang terinfeksi tuberkulosis secara laten

- MVA-85A sangat imunogenik pada populasi peserta ini.

\section{Pada orang dengan infeksi HIV}

Peserta dalam percobaan ini berusia 18-55 tahun dengan HIV positif, namun sehat dan tidak dalam medikasi ARV.

\section{Efek}

- Kejadian pruritus lebih tinggi dibandingkan dengan subjek yang tidak terinfeksi HIV, namun tidak ditemukan reaksi lokal yang berat. Reaksi lokal yang ditemukan ringan. Satu subjek di grup dosis rendah mengalami episode tunggal demam yang lebih tinggi dari $37.5^{\circ} \mathrm{C}$

- Kekhawatiran utama yang timbul terhadap vaksinasi pada individu yang terinfeksi HIV adalah kemungkinan bahwa sel T CD4 spesifik antigen akan menjadi target utama dari infeksi HIV yang berfungsi dalam status aktif, yang kemudian meningkatkan laju infeksi HIV dan mempercepat progresi penyakit. Namun pada studi kali ini, tidak ada bukti infeksi HIV lebih memilih menyerang sel T CD4 spesifik Ag85A.

Imunogenitas MVA-85A pada Pasien HIV

- Respon sel T spesifik antigen yang diinduksi dengan MVA 85A diukur dengan IFN- $\gamma$ ELISpot assay. Pada grup dengan dosis rendah, frekuensi sel T yang menyekresikan IFN- $\gamma$ yang berespon pada $85 \mathrm{~A}$ pada minggu pertama setelah vaksinasi meningkat dengan median 393 sfc/juta dibandingkan dengan awalnya sebelumnya vaksinasi yang diukur pada waktu screening, ada perubahan yang signifikan yang bertahan sampai minggu ke 24 setelah vaksinasi. Pada grup dengan dosis tinggi, peningkatan median sampai 502 sfc/juta tampak pada minggu 1 setelah vaksinasi, respon ini bertahan sampai 24 minggu. Pada kedua grup, respon sel $\mathrm{T}$ terhadap $85 \mathrm{~A}$ diikuti dengan peningkatan signifikan melebihi awal pada minggu pertama, walaupun respon minggu 24 hanya bertahan secara signifikan melebihi awal pada grup yang mendapat dosis tinggi. Tidak ada perbedaan signifikan dalam respon IFN- $\gamma$ di antara semua subjek di dosis rendah maupun dosis tinggi dalam periode follow up. Namun, tingkat respon lebih tinggi pada grup dengan dosis tinggi dibandingkan dengan grup dengan dosis rendah. Secara keseluruhan, respon sel T spesifik Ag85A sangat mirip dengan yang sebelumnya dilaporkan pada studi dengan subjek tanpa infeksi HIV $^{11}$.

- Respon sel T spesifik Ag85A pada grup dengan dosis rendah secara signifikan lebih rendah dibandingkan dengan yang studi yang dipublikasikan sebelumnya pada subjek tanpa infeksi HIV. Perbedaan ini tidak signifikan pada minggu pertama, yang memperlihatkan respon puncak, tetapi signifikan pada minggu ke-24 setelah vaksinasi. Tidak ada perbedaan signifikan pada respon awal di antara subjek yang terinfeksi HIV dan grup yang tidak terinfeksi HIV. Hal ini juga terjadi pada grup dengan dosis tinggi pada subjek yang terinfeksi HIV yang memperlihatkan respon yang secara signifikan lebih rendah dibandingkan pasien yang tidak terinfeksi HIV yang menerima dosis yang sama ${ }^{11}$.

- Tidak ada korelasi signifikan antara perhitungan CD4 pada saat screening dan saat respon puncak 85A tidak juga ada perbedaan HIV RNA pada saat screening dan saat respon imun maksimum. Empat subjek diketahui mempunyai LTBI, namun tidak terdapat perubahan signifikan setelah vaksinasi pada respon ESAT6/CFP10 pada subjek tersebut. Produksi kemokin/sitokin spesifik Ag85A oleh sel T CD4 meningkat secara signifikan setelah vaksinasi. Satu minggu setelah vaksinasi MVA-85A, lebih dari 40\% sel T CD4 spesifik Ag85A memproduksi IFN- $\gamma, \quad$ IL-2, MIP-1 $\beta$ dan TNF- $\alpha$ secara bersamaan dan tetap signifikan pada minggu kedua. Pada minggu ke-8 setelah vaksinasi, $60 \%$ sel T CD4 spesifik Ag85A masih memproduksi IFN- $\gamma$, IL-2, MIP-1 $\beta$ danTNF- $\alpha$. Produksi IFN- $\gamma$ dan TNF- $\alpha$ dipertahankan sampai 24 minggu. Produksi MIP-1 $\beta$ tidak dideteksi lebih dari 2 minggu setelah vaksinasi. Pada 2 minggu pertama setelah vaksinasi, sel T CD4 spesifik Ag85A memperlihatkan fungsi yang mirip pada grup yang terinfeksi HIV baik dosis tinggi maupun dosis rendah dengan dosis rendah terkontrol pada grup yang tidak terinfeksi $\mathrm{HIV}^{11}$.

\section{SIMPULAN}

- MVA-85A aman pada pasien dengan infeksi HIV

- MVA-85A imunogenik pada pasien dengan infeksi HIV sekalipun lebih rendah pada pasien tanpa infeksi HIV. 


\section{KEUNGGULAN VAKSIN MVA85A}

- Vaksin MVA85A memberi keuntungan pada pasien dengan infeksi laten tuberkulosis

- Vaksin MVA 85A memberi keuntungan pada pasien dengan infeksi HIV dan mampu memberi efek imunogenik dan aman dipakai.

\section{DAFTAR PUSTAKA}

1. Aditama $T$, Wongsokusumo B, Hudoyo A, Rusmiati A, Gani A, Nadia S, dkk. Perkembangan Teknologi, Perkembangan Kuman. J tuber Indonesia [Internet]. Agustus 2004 [dikutip tanggal 28 November 2011]; 3(2): ii-iv. Diakses di http://www.tbindonesia.or.id

2. Syahrini H. Tuberkulosis Paru Resistensi Ganda. Fakultas Kedokteran Universitas Sumatera Utara [Internet]. 2008 [dikutip tanggal 28 November 2011]. Diakses di http://repository.usu.ac.id

3. Triadmojo P. Perpustakaan Digital ITB [Internet]. Bandung: Institusi Teknologi Bandung; 2002 [dikutip tanggal 28 November 2011]. Diakses di http://digilib.itb.ac.id

4. Purwanti. Hidup Baru [Internet]. Jakarta: Media Indonesia; Jumat, 29 Agustus 2008 [dikutip tanggal 28 November 2011]. Diakses di http://www.mediaindonesia.com

5. Kumar V, Cotran R, Robbins S. Buku Ajar Patologi Edisi 7. Jakarta: Penerbit Buku Kedokteran EGC; 2007 Keshuma P. Tinjauan Pustaka. Universitas Sumatera Utara [Internet]. 2010 [Dikutip 2 Januari 2012]. Diakses di http://repository.usu.ac.id

6. Neilson A. Tuberkulosis Prevention in Travellers. Aus fam Ph. Oktober 2010 [dikutip tanggal 4 Januari 2012]; 39(10): hal 743-750. Diakses di http://www.racgp.org.au

7. Wikipedia The Free Encyclopedia [Internet]. United States: Nupedia. 7 Desember 2011 [dikutip tanggal 4 Januari 2012]. Diakses di http://en.wikipedia.org

8. Ronning D, Vissa V, Besrall G, Belisle J, Sacchettini J. Mycobacterium tuberkulosis Antigen 85A and 85C Structures Confirm Binding Orientation and Conserved Substrate Specificity. J of Bio Che. 10 Juni 2004 [dikutip tanggal 4 Januari 2012]; 279(35): 36771-36777. Diakses di http://www.jbc.org

9. Sander C, Pathan A, Beveridge N, Poulton I, Minassian A, Alder N, dkk. Safety and
Immunogenicity of a New Tuberkulosis Vaccine, MVA85A, in Mycobacterium tuberkulosisinfected Individuals. Ame J of Res and Cri C Med. 15 April 2009 [Dikutip tanggal 4 Januari 2012]; 179(8): 723-733. Diakses di http://ajrccm.atsjournals.org

10. Minassian A, Rowland R, Beveridge N, Poulton I, Satti I, Harris $S$, dkk. A Phase I study evaluating the safety and immunogenicity of MVA85A, a candidate $T B$ vaccine, in HIV-infected adults. BMJ Op. 2011 [dikutip tanggal 4 Januari 2012]; 1(2): 1-11. Diakses di http://www.ncbi.nlm.nih.gov 